\title{
KEANEKARAGAMAN LAMUN DAN MAKROZOOBENTOS SEBAGAI INDIKATOR KONDISI PERAIRAN PANTAI SINDHU, SANUR, BALI
}

\author{
I Made Sara Wijana ${ }^{1 *}$, Ni Made Ernawati ${ }^{2)}$, Made Ayu Pratiwi ${ }^{3)}$ \\ ${ }^{1)}$ Program Studi Biologi, FMIPA Universitas Udayana \\ ${ }^{2}$ Program Studi Manajemen Sumberdaya Perairan, FKP Universitas Udayana \\ ${ }^{3)}$ Program Studi Manajemen Sumberdaya Perairan, FKP Universitas Udayana \\ *Email: sarawijana@unud.ac.id
}

\section{ABSTRACT \\ SEAGRASS AND MACROZOOBENTHOS DIVERSITY AS AN INDICATOR OF WATERS CONDITION IN SINDHU BEACH, SANUR, BALI}

Sindhu Beach is part of the Sanur beach area. Sanur area is one of 11 strategic national tourism areas in Bali. Beach tourism activities have the potential to cause degradation of coastal ecosystems. Ecosystem changes can be determined using bioindicators. This study aims to determine the condition of the Sindhu Coast waters ecosystem based on seagrass diversity and macrozoobenthos as indicators. This research was conducted in November 2019 at Sindhu Beach. Seagrass observations and macrozoobenthos sampling were carried out at four stations with three replications at each station. Data and samples were collected using the quadratic transect method. Eight species of seagrass were found in Sindhu Beach with a percentage of cover between $16.33 \%-63.37 \%$ and density between 1572 ind $/ \mathrm{m}^{2}-3314.4$ ind $/ \mathrm{m}^{2}$. The average value of the seagrass diversity index was 1.24 , the average uniformity index was 0.78 , and the average dominance index was 0.32. Types of macrozoobenthos found were 23 species with abundances ranging from 2.33 ind $/ \mathrm{m}^{2}-28.33$ ind $/ \mathrm{m}^{2}$. The average value of macrozoobenthos uniformity index is 1.50 , the average diversity index is 0.68 and the average dominance index is 0.36 . Based on the index value shows that the waters of Sindhu Beach are in good condition or there is no ecologically significant pressure.

Keyword: Indicator, diversity, macrozoobenthos, seagrass, water condition

\section{PENDAHULUAN}

Ekosistem lamun memiliki sifat yang sangat unik, dia merupakan merupakan salah satu tumbuhan sejati atau tumbuhan tingkat tinggi yang dapat hidup dengan baik dalam kondisi salinitas tinggi. Lamun memiliki rizoma, akar dan daun sejati. Lamun merupakan satu-satunya tumbuhan berbunga (Angiospermae) yang hidup terbenam di dalam perairan. Lamun memiliki kemampuan beradaptasi yang sangat baik terhadap kondisi perairan yang memiliki salinitas tinggi (Kawaroe, 2009). Susetiono (2004) menambahkan bahwa lamun (seagrass) umumnya hidup di perairan laut dangkal dan seluruh proses kehidupannya berlangsung di lingkungan perairan tersebut. Selain memiliki keunikan dalam hal beradaptasi dengan lingkungan, komunitas lamun juga memiliki bermacam-macam fungsi dalam ekosistem perairan diantaranya fungsi ekologi dan ekonomi. Fungsi ekologi yang dimiliki oleh padang lamun antara lain adalah sebagai tempat berlindung (nursery ground), tempat mencari makan (feeding ground), dan sebagai tempat memijah (spawning ground) bagi berbagai jenis biota laut seperti ikan, udang, kekerangan, dan lain-lain. Selain itu lamun juga merupakan makanan bagi penyu hijau dan dugong.

Komunitas fauna dan/atau biota yang sering dijumpai berasosiasi dengan lamun adalah komunitas makrozoobentos. Makrozoobentos adalah komponen biologi perairan yang memegan peran penting dalam sistem ekologi pantai dan sering dijadikan bioindikator untuk menilai kualitas dan tingkat cemaran suatu ekosistem perairan. Hal itu karena makrozoobentos memiliki bebrapa sifat hidup yang memenuhi persyaratan biota indikator yaitu hidupnya yang cenderung menetap (sesile), pergerakan dan mobilitas 
rendah, peka terhadap beberapa bahan pencemar, dan memiliki daya adaptasi bervariasi terhadap kondisi lingkungan (Purnami et al., 2010; Lumingas et al., 2011; Sharma et al., 2013; Trisnawaty et al., 2013).

Pantai Sindhu terletak dalam satu garis pantai dengan pantai-pantai lain di kawasan Sanur. Kawasan Pantai Sanur sebagai destinasi wisata internasional telah ditetapkan sebagai kawasan strategis pariwisatan nasional (KSPN). Selain sebagai tempat pariwisata, Pantai Shindu juga memiliki fungsi social religius seperti sebagai tempat melangsungkan beberapa jenis upacara, sebagai tempat penambatan perahu-perahu nelayan. Kawasan pariwisata ditandai oleh adanya berbagai sarana, prasarana dan fasilitas penunjang kepariwisataan yang berpotensi menimbulkan degradasi lingkungan, sehingga lingkungan dalam situasi kritis (Casagrandi et al., 2002). Kegiatan wisata di Pantai Sindhu cepat atau lambat juga dapat meyebabkan penurunan kualitas perairan pantai tersebut. Salah satu pendekatan yang dapat digunakan untuk mengetahui kondisi suatu perairan adalah pendekatan secara biologis yaitu dengan menggunakan organisme yang dikenal sebagai bioindikator (Prato et al., 2009; Ritter et al., 2009; Sundaravaman et al., 2012). Kelebihan Pantai Sindhu selain karena keindahan dengan pasir putihnya, keindahan hamparan ekosistem padang lamun yang cukup luas menambah keunikan pantai ini (Pratiwi dan Ernawati, 2018). Oleh karena itu komunitas lamun dan makrozoobentos yang berasosiasi dengan lamun bisa digunakan sebagai salah satu indikator untuk menggambarkan kondisi perairan Pantai Sindhu.

\section{METODOLOGI}

\subsection{Waktu dan Tempat}

Penelitian ini dilaksanakan pada bulan November 2019 di Pantai Sindhu, Sanur, Bali. Identifikasi jenis lamun dilakukan secara langsung saat pengamatan di lokasi penelitian sedangkan identifikasi sampel mokrozoobentos dilakukan di Laboratorium Perikanan, Fakultas Kelautan dan Perikanan, Universitas Udayana. Lokasi penelitian dibagi menjadi empat stasiun pengamatan (Gambar 1). Masing-masing stasiun terdiri dari tiga titik (plot) sebagai ulangan yang mengarah tegak lurus garis pantai.

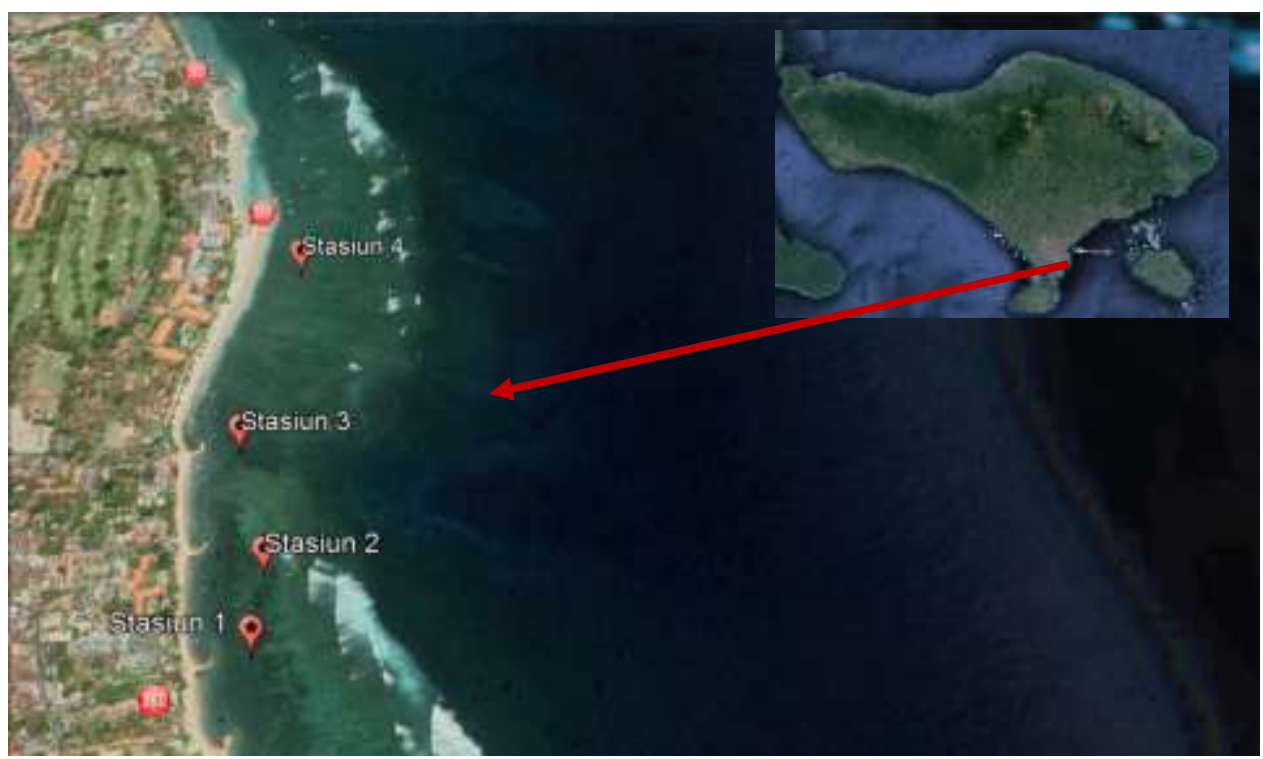

Gambar 1.

Lokasi Pengamatan dan Pengambilan Sampel 


\subsection{Metode Pengamatan \\ Pengambilan Data Lamun}

dan

Pengamatan dan pengambilan data lamun dilakukan pada saat air surut menggunakan transek kuadrat berukuran $50 \times 50 \mathrm{~cm}$. Transek tersebut dibagi menjadi 9 ruang dan masing-masing ruang berukuran $16,67 \mathrm{~cm} \times 16,67 \mathrm{~cm}$. Dari 9 ruang tersebut, data jumlah tegakan lamun diambil hanya pada 5 ruang yaitu di masing-masing pojok (4 ruang) dan di tengah (1 ruang). Sedangkan perhitungan persentase penutupan lamun dilakukan dengan metode seagrass percent cover standards. Metode tersebut dilakukan dengan mengestimasi persentase luas tutupan lamun pada setiap transek kuadran (McKenzie et al., 2003).

\subsection{Metode Pengambilan Sampel Makrozoobentos}

Pengambilan contoh makrozoobenthos di dasar perairan dilakukan dengan menggali substrat dasar seluas 1 x $1 \mathrm{~m}$ menggunakan skop sebanyak 25 kali ulangan dan dikompositkan. Substrat tersebut kemudian diayak atau disaring menggunakan ayakan (mata saringan $1 \mathrm{~mm}^{2}$ ). Makrozoobentos yang tersaring kemudian dimasukkan ke dalam wadah sampel dan diawetkan pada larutan alkohol 70\%, kemudian diidentifikasi di laboratorium.

\subsection{Analisi Data}

\subsubsection{Presentase tutupan lamun}

Estimasi persetase tutupun pada ekosistem lamun dilakukan terhadap tutupan lamun dan tutupan makro algae. Penutupan lamun merupakan estimasi persentase luasan dalam plot transek yang tertutupi lamun.

Tabel 2. Kondisi Lamun Berdasarkan Kerapatan
Persentase tutupan lamun adalah proporsi luas substrat yang ditutupi vegetasi lamun dalam satu satuan luas yang diamati tegak lurus dari atas (Brower et al, 1990). Data estimasi yang didapat pada setiap plot kemudian di rata-rata per stasiun pengamatan. Kondisi padang lamun berdasarkan persentase penutupannya dikelompokkan menjadi beberapa kategori seperti yang tersaji dalam Tabel 1 .

Tabel 1. Kondisi Padang Lamun Berdasarkan Persentase Penutup

\begin{tabular}{lll}
\hline Kondisi & $\begin{array}{l}\text { Penutupan } \\
(\%)\end{array}$ \\
\hline Baik & Kaya/Sehat & $\geq 60$ \\
Rusak & Kurang Kaya/Kurang Sehat & $30-59.9$ \\
& Miskin & $\leq 29.9$ \\
\hline
\end{tabular}

Sumber: KepMen LH No. 200 Th. 2004

\subsubsection{Kerapatan Lamun dan Kelimpahan Makrozoobentos}

Kerapatan jenis merupakan jumlah individu yang ditemukan per satuan area pengamatan. Kerapatan jenis (Di) yaitu jumlah individu jenis i dibagi jumlah total area yang diukur (Bengen, 2003) yang umumnya dinyatakan dalam satuan individu per meter persegi $\left(\mathrm{Ind} / \mathrm{m}^{2}\right)$ :

$$
\mathrm{Di}=\frac{n i}{A}
$$

Dimana, Di $=$ kerapatan jenis-i; ni $=$ jumlah total individu dari jenis-i, $\mathrm{A}=$ luas areal total pengamatan/pengambilan contoh. Kerapatan lamun dibagi menjadi 5 kategori mulai dari sangat jarang sampai sangat rapat dengan nilai-nilai seperti yang tersaji dalam Tabel 2.

\begin{tabular}{ccc}
\hline Skala & Kerapatan/kelimpahan $\left(\mathbf{I n d} / \mathbf{m}^{\mathbf{2}}\right)$ & Kondisi \\
\hline 1 & $<25$ & Sangat Jarang \\
2 & $25-75$ & Jarang \\
3 & $75-125$ & Agak Rapat \\
4 & $125-175$ & Rapat \\
5 & $>175$ & Sangat Rapat \\
\hline
\end{tabular}

Sumber: Haris dan Gosari, 2012 


\subsubsection{Indeks Keanekaragaman}

Perhitungan indeks keanekaragaman lamun dan makrozoobentos mengacu pada indeks keanekaragaman Shannon-Wiener $\left(\mathrm{H}^{\prime}\right)$ dengan rumus sebagai berikut (Krebs, 1972):

$$
\mathrm{H}^{\prime}=-\sum_{i=1}^{n} p i \ln p i
$$

Dimana, $\mathrm{H}^{\prime}=$ indeks keanekaragaman Shannon-Wiener; pi = perbandingan jumlah individu/tegakan spesies ke-i (ni) terhadap jumlah total individu/tegakan $(\mathrm{N})=\mathrm{ni} / \mathrm{N}$. Kriteria indeks keanekaragaman ShannonWiener dikelompokkan ke dalam 3 kategori seperti yang tersaji dalam Tabel 3 .

Tabel 3. Kriteria Tingkat Indeks Keanekaragaman

\begin{tabular}{cl}
\hline Indeks Keanekaragaman & \multicolumn{1}{c}{ Kategori } \\
\hline $\mathrm{H}^{\prime}>3$ & Tingkat kenaekaragaman tinggi \\
$3 \geq \mathrm{H}^{\prime} \geq 1$ & Tingkat keanekaragaman sedang \\
$\mathrm{H}^{\prime} \leq 1$ & Tingkat keanekaragaman rendah \\
\hline
\end{tabular}

Sumber: Alhanif (1996)

\subsubsection{Indeks Keseragaman}

Perhitungan nilai indeks keseragaman lamun dan makrozoobentos mengacu pada rumus berikut :

$$
\mathrm{E}=\frac{H^{\prime}}{H^{\prime} \max }
$$

Tabel 4. Kriteria Tingkat Indeks Keseragaman
Dimana, $\mathrm{E}=$ indeks keseragaman $; \mathrm{H}^{\prime}=$ Indeks Keanegaragaman; $\mathrm{H}^{\prime} \max =$ indeks keanekaragaman maksimum, $($ Hmaks $=\ln \mathrm{S})$ dan $S$ adalah jumlah total spesies. Kriteria nilai indeks keseragaman dikelompokkan ke dalam 3 kategori seperti tersaji dalam Tabel 4:

\begin{tabular}{cl}
\hline Nilai Keseragaman $(\mathbf{E})$ & \multicolumn{1}{c}{ Kategori } \\
\hline $1,0 \geq \mathrm{E}>0,6$ & $\begin{array}{l}\text { Kerseragaman tinggi yang berarti jumlah individu } \\
\text { spesies yang satu dengan spesies lainnya tidak jauh } \\
\text { berbeda, kondisi lingkungan dikatakan masih stabil. }\end{array}$ \\
& $\begin{array}{l}\text { Keseragaman sedang, menandakan bahwa kondisi } \\
\text { lingkungan tidak terlalu stabil. }\end{array}$ \\
& Keseragaman rendah yang berarti kekayaan individu \\
& yang dimiliki oleh masing-masing jenis jauh berbeda, \\
& kondisi lingkungan tidak stabil kerana mengalami \\
& tekanan.
\end{tabular}

Sumber: Romimohtarto dan Juwana (2001)

\subsubsection{Indeks Dominansi}

Nilai indeks dominansi merupakan suatu gambaran tentang ada atau tidaknya suatu spesies yang mendominasi di suatu wilayah perairan. Perhitungan nilai indeks dominasi mengacu pada rumus berikut :

$$
C=\sum_{i=1}^{n} p i^{2}
$$

Dimana, $\mathrm{C}=$ indeks dominasi; $\mathrm{pi}=$ proporsi jumlah individu pada spesies lamun; $\mathrm{N}=$ jumlah individu seluruh spesies; $\mathrm{ni}=$ jumlah individu dari spesies ke-i. Kriteria nilai indeks dominansi dikelompokkan ke dalam 3 kategori seperti tersaji dalam Tabel 5. 
Tabel 5. Kriteria Tingkat Indeks Dominansi

\begin{tabular}{cl}
\hline Nilai Dominansi $(\mathbf{C})$ & \multicolumn{1}{c}{ Kategori } \\
\hline $0,6<\mathrm{C} \leq 1,0$ & $\begin{array}{l}\text { Dominansi tinggi, terdapat salah satu spesies yg jumlah } \\
\text { individunya sangat banyak dan jauh berbedadengan } \\
\text { spesies yang lainnya, kondisi lingkungan tidak stabil } \\
\text { karena adanya suatu tekanan ekologi. }\end{array}$ \\
$0,4<\mathrm{C} \leq 0,6$ & $\begin{array}{l}\text { Dominansi sedang, kondisi lingkungan cukup stabil } \\
0 \leq \mathrm{C} \leq 0,4\end{array}$ \\
& $\begin{array}{l}\text { Dominansi rendah, tidak terjadi dominasi antar spesies, } \\
\text { kondisi lingkungan stabil, tidak terjadi tekanan ekologis } \\
\text { terhadap biota di lingkungan tersebut }\end{array}$ \\
\hline
\end{tabular}

Sumber: Rappe (2010)

\section{HASIL DAN PEMBAHASAN}

\subsection{Presentase Tutupan Lamun}

Persentase tutupan jenis lamun berbeda pada setiap stasiun pengamatan di Pantai Sindhu. Persentase tutupan jenis tertinggi yaitu jenis Halodule uninervis sebesar $24,67 \%$ pada stasiunpengamatan 1 , sedangkan persentase tutupan jenis terendah yaitu jenisThalassia hemprichii sebesar $0,67 \%$ pada Stasiunpengamatan 1. Persentase tutupan lamun total tertinggi terdapat pada stasiun 2 sebesar 63,37\%, sedangkan persentase tutupan lamun total terendah terdapat pada stasiun 4 sebesar 16,33\% (Tabel 6). Berdasarkan kriteria penilaian status padang lamun (KepMen LH, 2004), pada stasiun pengamatan 1 dan 2 termasuk kriteria tutupan lamun $>60 \%$, dikatakan padang lamun tersebut dalam kondisi sehat/kaya, stasiun pengamatan 3 termasuk kriteria tutupan lamun 30-59,9\%, sehingga dikatakan kondisi padang lamun kurang kaya/kurang sehat, dan stasiun pengamatan 4 termasuk kriteria tutupan lamun $<29,9 \%$, sehingga dikatakan kondisi padang lamun miskin. Rata-rata tutupan lamun pada keempat stasiun pengamatan yaitu $48,83 \%$ yang termasuk pada kriteria $30-59,9 \%$, sehingga memiliki kondisi lamun kurang kaya/kurang sehat. Estimasi penutupan lamun dapat dipengaruhi oleh kepadatan yang tinggi serta kondisi pasang surut suatu perairan. Selain itu, bentuk morfologi dan ukuran suatu spesies lamun memiliki hubungan yang erat dan sangat berpengaruh terhdap persentase tutupan lamun (Simon et al., 2013).

Tabel 6.Persentase Tutupan Jenis Lamun (\%) di Pantai Sindhu

\begin{tabular}{clcccc}
\hline No. & \multicolumn{1}{c}{ Jenis Lamun } & Stasiun 1 & Stasiun 2 & Stasiun 3 & Stasiun 4 \\
\hline 1 & Enhalus accroides & 7,00 & 2,33 & - & 1,00 \\
2 & Halodule uninervis & 24,67 & 8,33 & 20,00 & - \\
3 & Halodule pinifolia & - & - & 2,33 & 6,33 \\
4 & Halophila ovalis & - & - & - & 3,33 \\
5 & Cymodocea serrulata & 10,67 & 28,67 & 2,67 & 5,67 \\
6 & Cymodocea rotundata & - & - & 1,00 & - \\
7 & Thalassia hemprichii & 0,67 & 8,00 & 7,67 & - \\
8 & Syringodium isoetifolium & 17,67 & 16,33 & 21,00 & - \\
\hline & Persentase Total & $\mathbf{6 0 , 6 7}$ & $\mathbf{6 3 , 6 7}$ & $\mathbf{5 4 , 6 7}$ & $\mathbf{1 6 , 3 3}$ \\
\hline
\end{tabular}




\subsection{Komposisi Jenis dan Kelimpahan Lamun dan Makrozoobentos}

Jenis lamun yang ditemukan di Pantai Sindhu sebanyak 8 jenis. Jenis-jenis tersebut yaitu Enhalus accroides, Halodule uninervis, Halodule pinifolia, Halophila ovalis, Cymodocea serrulata, Cymodocea rotundata, Thalassia hemprichii dan Syringodium isoetifolium. Jenis Cymodocea serrulata memiliki penyebaran yang merata yang ditandai jenis ini ditemukan pada setiap stasiun pengamatan. Jenis Cymodocea rotundata merupakan jenis yang hanya ditemukan pada satu stasiun pengamatan saja (Stasiun 3). Jumlah jenis terbanyak ditemukan pada stasiun 3 (sebanyak 6 jenis), sedangkan jumlah jenis terendah ditemukan pada stasiun 4 (sebanyak 4 jenis) (Tabel 7). Delapan jenis lamun yang ditemukan di Pantai Sindhu tergolong cukup tinggi yaitu sekitar 61,54\% dari total 13 Jenis lamun yang terdapat di Indonesia. P2O-LIPI (2014) menyatakan bahwa di Indonesia terdapat 13 jenis lamun yaitu, Enhalus accroides, Thalassia hemprichii, Cymodocea serrulata, Cymodocea rotundata, Halophila minor, $H$. ovalis, $H$. tricostrata, $H$. sulawesii, $H$. decipiens, Halodule uninervis, $H$. pinifolia, Thalassodendron cilliatum, Syringodium isoetifolium.

Syringodium isoetifolium merupakan jenis lamun yang memiliki kerapatan tertinggi yaitu sebesar $1200 \mathrm{ind} / \mathrm{m}^{2}$, sedangan kerapatan jenis lamun terendah yaitu Enhalus accroides sebesar 2,4 ind $/ \mathrm{m}^{2}$. Kerapatan lamun tertinggi terdapat pada stasiun pengamatan 3 yaitu sebanyak $3314,4 \mathrm{ind} / \mathrm{m}^{2}$, sedangkan kerapatan lamun terendah terdapat pada stasiun pengamatan 2 yaitu sebanyak $1572 \mathrm{ind} / \mathrm{m}^{2}$ (Tabel 7). Haris dan Gosari (2012) menyatakan bahwa kerapatan individu lamun > $175 \mathrm{ind} / \mathrm{m}^{2}$ termasuk dalam kondisi sangat rapat. Kondisi kerapatan total lamun pada setiap stasiun pengamatan di Pantai Sindhu termasuk > $175 \mathrm{ind} / \mathrm{m}^{2}$, sehingga dapat diartikan bahwa kerapatan lamun di Pantai Sindhu termasuk dalam kondisi sangat rapat

Tabel 7. Kerapatan Jenis Lamun (ind $/ \mathrm{m}^{2}$ ) di Pantai Sindhu

\begin{tabular}{clcccc}
\hline No. & \multicolumn{1}{c}{ Jenis Lamun } & Stasiun 1 & Stasiun 2 & Stasiun 3 & Stasiun 4 \\
\hline 1 & Enhalus accroides & 43,2 & 21,6 & - & 2,4 \\
2 & Halodule uninervis & 763,2 & 168 & 720 & - \\
3 & Halodule pinifolia & - & - & 93,6 & 746,4 \\
4 & Halophila ovalis & - & - & - & 566,4 \\
5 & Cymodocea serrulata & 369,6 & 232,8 & 1077,6 & 256,8 \\
6 & Cymodocea rotundata & - & - & 55,2 & - \\
7 & Thalassia hemprichii & 24 & 276 & 168 & - \\
8 & Syringodium isoetifolium & 508,8 & 523,2 & 1200 & - \\
\hline & Kerapatan Total & $\mathbf{1 7 0 8 . 8}$ & $\mathbf{1 2 2 1 , 6}$ & $\mathbf{3 3 1 4 , 4}$ & $\mathbf{1 5 7 2}$ \\
\hline & Jumlah Jenis & $\mathbf{5}$ & $\mathbf{5}$ & $\mathbf{6}$ & $\mathbf{4}$ \\
\hline
\end{tabular}

Jenis makrozoobentos yang ditemukan di Pantai Sindhu pada penelitian ini sebanyak 23 jenis dengan komposisi yang berbeda-beda pada setiap stasiunnya. Jumlah jenis terbanyak ditemukan pada stasiun 1 yakni sebanyak 15 jenis, sedangkan jumlah jenis terendah ditemukan pada stasiun 3 yakni sebanyak 6 jenis saja. Secara keseluruhan komposisi jenis tertinggi yang ditemukan adalah jenis Ophiura savignyi, yang diikuti oleh Diadema setosum. Sedangkan komposisi jenis terendah yang ditemukan adalah jenis 
Synapta maculate, Cardium sp., Protoreaster nodosus, Macropthalmus convexus, dan Holothuria atra.

Kelimpahan total makrozoobentos bervariasidi setiap stasiun. Kelimpahan tertinggi terdapat pada stasiun 4 dengan nilai
$28,33 \mathrm{ind} / \mathrm{m}^{2}$, sedangkan kelimpahan terendah terdapat pada stasiun 3 dengan nilai 2,33 ind $/ \mathrm{m}^{2}$. Secara rinci kelimpahan masingmasing jenis makrozoobentos di Pantai Sindhu dapat dilihat pada Tabel 8.

Tabel 8. Kelimpahan Jenis Makrozoobentos (ind $/ \mathrm{m}^{2}$ ) di Pantai Sindhu

\begin{tabular}{|c|c|c|c|c|c|}
\hline No & Jenis & Stasiun 1 & Stasiun 2 & Stasiun 3 & Stasiun 4 \\
\hline 1 & Nereis sp. & 0,33 & 0,33 & 0,33 & 0,67 \\
\hline 2 & Ophiura savignyi & 0,33 & 1,00 & - & 21,67 \\
\hline 3 & Ophiocoma erinaceus & - & - & - & 1,33 \\
\hline 4 & Tripneustes gratilla & $0 ’ 33$ & 0,33 & 0,33 & - \\
\hline 5 & Temnopleurus alexandrii & $0 ’ 67$ & - & 0,33 & - \\
\hline 6 & Diadema setosum & 11,00 & - & - & - \\
\hline 7 & Diadema antillarum & 1,00 & 0,33 & - & - \\
\hline 8 & Synapta maculate & - & 0,33 & - & - \\
\hline 9 & Echinotrix calamaris & 0,67 & - & - & - \\
\hline 10 & Echinometra lucunter & 0,67 & - & - & - \\
\hline 11 & Erronea sp. & 0,67 & - & - & - \\
\hline 12 & Donax faba & 0,33 & - & - & - \\
\hline 13 & Austromitras. & 0,33 & - & - & 1,00 \\
\hline 14 & Cardium sp. & 0,33 & - & - & - \\
\hline 15 & Protoreaster nodosus & 0,33 & - & - & - \\
\hline 16 & Henricia leviuscula & 0,33 & 0,33 & - & - \\
\hline 17 & Macropthalmus convexus & - & 0,33 & - & - \\
\hline 18 & Holothuria atra & - & - & 0,33 & - \\
\hline 19 & Coenobita lila & - & 2,67 & - & 0,67 \\
\hline 20 & Cymbiola vespertilio & 0,33 & - & 0,33 & 0,33 \\
\hline 21 & Morula sp. & - & - & - & 0,67 \\
\hline 22 & Seulocia sp. & - & - & 0,67 & - \\
\hline \multirow[t]{3}{*}{23} & Vexillum intermedium & - & - & - & 2,00 \\
\hline & Kelimpahan Total & 17,67 & 5,67 & 2,33 & 28,33 \\
\hline & Total Jenis & 15 & 8 & 6 & 8 \\
\hline
\end{tabular}

\subsection{Indeks}

Keanekaragaman,

Keseragaman, dan Dominansi Lamun dan Makrozoobentos

Indeks keanekaragaman, keseragaman dan dominansi mampu menggambarkan tingkat kestabilan suatu komunitas dalam suatu ekosistem. Selain itu, ketiga indeks tersebut juga dapat menggambarkan kondisi lingkungan karena kondisi lingkungan sangat berpengaruh terhadap tingkat spesies sebagai komponen terkecil penyusunan populasi yang membentuk komunitas.

Rata-rata indeks keanekaragaman lamun di Pantai Sindhu sebesar 1,24 (Tabel 9) dan Rata-rata nilaiindeks keanekaragaman makrozoobentos di Pantai Sindhu sebesar 1,50 (Tabel 10). Nilai tersebut termasuk dalam kategori indeks keanekaragaman sedang yang artinya bahwa lokasi tersebut memiliki produktivitas cukup, kondisi ekosistem cukup seimbang dan tekanan 
ekologisnya sedang. Brower et al. (1990), menyatakan bahwa keanekaragaman jenis merupakan gambaran dari suatu struktur komunitas. Apabila proporsi antar jenis secara keseluruhan tidak jauh berbeda maka dapat dikatakan bahwa komunitas tersebut memiliki keanekaragaman jenis tinggi. Nilai indeks keanekaragaman lamun dan makrozoobentos pada setiap stasiun pengamatan tergolong dalam kategori $3 \geq \mathrm{H}^{\prime}>1$, yang artinya memiliki keanekaragaman sedang, penyebaran sedang dan kestabilan komunitas sedang (Alhanif, 1996).

Rata-rata nilai indeks keseragaman lamun di Pantai Sindhu sebesar 0,78 (Tabel 9) dan rata-rata nilai indeks keseragaman makrozoobentosnya sebesar 0,68 (Tabel 10). Nilai indeks keseragaman menunjukan kestabilan suatu komunitas (Pratiwi dan Ernawati, 2018). Indeks keseragaman pada setiap stasiun pengamatan termasuk kedalam kategori $1,0 \geq \mathrm{E}>0,6$, yang artinya memiliki keseragaman tinggi dan komunitas stabil (Romimohtarto dan Juwana, 2001). Apabila semakin kecil indeks keseragaman maka semakin besar perbedaan jumlah antara spesies (adanya dominansi), begitu juaga sebaliknya apabila semakin besar indeks keseragaman maka semakin kecil perbedaan jumlah antara spesies sehingga kecenderungan dominasi oleh jenis tertentu tidak ada (Ruswahyuni, 2008).

Tabel 9. Indeks Keanekaragaman, Keseragaman, dan Dominansi Lamun di Pantai Sindhu

\begin{tabular}{cccc}
\hline $\begin{array}{c}\text { Stasiun } \\
\text { Pengamatan }\end{array}$ & $\begin{array}{c}\text { Indeks } \\
\text { Keanekaragaman }\left(\mathbf{H}^{\prime}\right)\end{array}$ & $\begin{array}{c}\text { Indeks } \\
\text { Keseragaman }(\mathbf{E})\end{array}$ & $\begin{array}{c}\text { Indeks } \\
\text { Dominansi }(\mathbf{C})\end{array}$ \\
\hline 1 & 1,21 & 0,75 & 0,34 \\
2 & 1,36 & 0,85 & 0,29 \\
3 & 1,39 & 0,77 & 0,29 \\
4 & 1,03 & 0,74 & 0,38 \\
\hline Rata-rata & $\mathbf{1 , 2 4}$ & $\mathbf{0 , 7 8}$ & $\mathbf{0 , 3 2}$ \\
\hline
\end{tabular}

Tabel 10. Indeks Keanekaragaman, Keseragaman, dan Dominansi Makrozoobentos di Pantai Sindhu

\begin{tabular}{cccc}
\hline $\begin{array}{c}\text { Stasiun } \\
\text { Pengamatan }\end{array}$ & $\begin{array}{c}\text { Indeks } \\
\text { Keanekaragaman }\left(\mathbf{H}^{\prime}\right)\end{array}$ & $\begin{array}{c}\text { Indeks } \\
\text { Keseragaman }(\mathbf{E})\end{array}$ & $\begin{array}{c}\text { Indeks } \\
\text { Dominansi (C) }\end{array}$ \\
\hline 1 & 1,63 & 0,60 & 0,40 \\
2 & 1,66 & 0,80 & 0,27 \\
3 & 1,75 & 0,84 & 0,18 \\
4 & 0,97 & 0,47 & 0,60 \\
\hline Rata-rata & $\mathbf{1 , 5 0}$ & $\mathbf{0 , 6 8}$ & $\mathbf{0 , 3 6}$ \\
\hline
\end{tabular}

Nilai indeks keseragaman lamun di Pantai Sindhu menandakan bahwa tidak ada perbedaan jumlah jenis lamun dan makrozoobentos yang terlalu tinggi yang berarti distribusi masing-masing jenis cukup seimbang tidak ada dominansi dari suatu jenis tertentu. Hal ini juga didukung dengan nilai indeks dominansi pada setiap stasiun pengamatan yang termasuk dalam kategori dominansi rendah $(0 \leq \mathrm{C} \leq 0,5)$ dengan nilai 0,32 untuk lamun (Tabel 9) dan 0,36 untuk makrozoobentos (Tabel 10). Rendahnya nilai dominansi di Pantai Sindhu menunjukan bahwa tidak terdapat spesies yang secara ekstrim mendominasi keberadaan spesies lainnya, yang biasanya didukung oleh lingkungan yang stabil dan tidak terdapat tekanan ekologis terhadap keberadaan biota tersebut. Berdasarkan nilai Indeks keanekaragaman, keseragaman, dan dominansi yang didapat mengindikasikan bahwa struktur komunitas lamun di Pantai Sindhu masih dalam kondisi stabil. 


\section{SIMPULAN DAN SARAN}

\subsection{Simpulan}

Hamparan asosiasi padang lamun dan makrozoobentos di Pantai Shindu termasuk ke dalam kategori yang masih baik. Jumlah jenis lamun yang berhasil ditemukan di Pantai Sindhu dalam penelitian ini sebanyak 8 jenis dan makrozoobentos sebanyak 23 jenis. Nilai indeks ekologis (keanekaragaman, keseragaman dan dominansi) lamun dan makrozoobentos di Pantai Sindhu menunjukkan bahwa kondisi perairan Pantai Sindhu masih baik dan belum ada tekanan yang signifikan secara ekologis.

\subsection{Saran}

Diperlukan adanya pemantauan secara berkala terhadap struktur komunitas lamun dan biota asosiasinya dengan menambahkan beberapa parameter seperti parameter fisikakimia perairan dan kandungan bahan organik pada substrat dasar peraira yang mendukung kehidupan lamun dan biota asosiasinya tersebut. Selain itu perlu dikaji dari aspek pariwisatanya yang juga berpotensi mempengaruhi keberlanjutan ekosistem lamun di Pantai Sindhu baik secara langsung maupun tidak langsung.

\section{DAFTAR PUSTAKA}

Alhanif, R. 1996. Struktur komunitas lamun dan kepadatan perifiton pada padang lamun di Perairan Pesisir Nusa Lembongan, Kecamatan Nusa Penida, Provinsi Bali [skripsi]. Bogor : Fakultas Perikanan dan Ilmu Kelautan, Institut Pertanian Bogor. 127 hal.

Bengen, D.G. 2003. Ekosistem dan Sumberdaya Pesisir dan Laut serta Pengelolaan Secara Terpadu dan Bekelanjutan. In: Koleksi Dokumen Proyek Pesisir 1997-2003 (Knight, M dan S.Tighe, editor). Coastal Resources Center, University of Rhode Island, Narragansett, Rhode Island, USA.

Brower, J.E. dan J.H Zar. 1990. Field and Laboratory Methods for General
Ecology. W. M. Brown Company Publ. Dubuque Lowa.

Casagrandi R, Rinaldi S. 2002. A Theoretical Approach to Tourism Sustainability. International Institute for Applied Systems Analysis Schlossplatz 1 A2361 Laxenburg, Austria.

Haris, A., dan J.A. Gosari. 2012. Studi Kerapatan dan Penutupan Jenis Lamun di Kepulauan Spermonde. Torani. Jurnal Ilmu Kelautan dan Perikanan, 22 (3): 256-162.

Kawaroe M. 2009. Perspektif lamun sebagai blue carbon sink di laut. Paper dipresentasikan dalam Lokakarya Lamun 18 November 2009.

Kementrian Lingkungan Hidup. 2004. Salinan Keputusan Menteri Lingkungan Hidup Nomor 200 tentang Kriteria Baku Kerusakan dan Pedoman Penentuan Status Padang Lamun. Jakarta

Krebs CJ. 1972. The Experimental Analysis of Distribution and Abundance. New York (US): Harper \& Row Publisher.

Lumingas L.J.L., Moningkey R.D., Alex D.K., 2011. Efek Stres Anthropogenic terhadap Struktur Komunitas Makrozoobentik Substrat Lunak Perairan Laut Dangkal di Teluk Buyat, Teluk Totok dan Selat Likupang (Semenanjung Minahasa, Sulawesi Utara). Jurnal Matematika dan Sains, 16 (2): 95-105.

McKenzie, L.J. 2003. Guidlines For the Rapid Assessment and Mapping of Tropical Seagrass Habitats. QFS, NFC, Cairns. $46 \mathrm{pp}$

P2O-LIPI [Pusat Penelitian OseanografiLembaga Ilmu Pengetahuan Indonesia]. 2014. Modul Pelatihan Taksonomi Biota Laut [edisi pertama].

Pratiwi, M.A. dan Ernawati, N.M. 2018. Struktur Komunitas Ekosisem Padang Lamun Pada Daerah Intertidal di Pantai Sanur, Bali. Ecotrophic, 12 (1): 50-56. 
Prato S, Morgana JG, La Valle P, Finoia MG, Lattanzi L, Nicoletti L, Ardizzone GD, Lzzo G. 2009. Application of biotic and taxonomic distinctness indices in assessing the ecological quality status of two coastal lakes: Gaprolace and Foglino lakes (Central Italy). Ecol. Indic, 9 (3): 568-583.

Purnami AT, Sunarto, Setyono P., 2010. Study of bentos community based on diversity and similarity index in Cengklik DAM Boyolali. Ekologi Sains, 2 (2): 50-65.

Rappe, R.A. 2010. Struktur komunitas ikan pada padang lamun yang berbeda di Pulau Barrang Lompo. Jurnal Ilmu dan Teknologi Kelautan Tropis, 2 (2): 6273.

Ritter KJ, Huff DD, Oakden JM, Thompson B, Velarde RG, Cadien DB, Ranasinghe JA, Weisberg SB, Smith RW, Montagne DE. 2009. Calibration and evaluation of five indicators of benthic community condition in two California bay and estuary habitats. Mar. Pollut. Bull., 59 (3): 5-13.

Romimohtarto, K. dan S. Juwana. 2001. Biologi Laut. Ilmu Pengetahuan Tentang Biota Laut. Jakarta : Djambatan.

Ruswahyuni, R. 2008. Hubungan antara kelimpahan meiofauna dengan tingkatan kerapatan lamun yang berbeda di Pantai Pulau Panjang Jepara. Jurnal Saintek Perikanan, 4 (1): 35-41.

Sharma R., Kumar A., Vyas V. 2013. Diversity of macrozoobenthos in Morand River-A Tributary of Ganjal River in Narmada Basin. International Journal Adv Fish Aquatic Science, 1 (1): 57-65.

Simon, I. P., \& Rifai, H. 2013. Struktur komunitas padang lamun di Perairan Pulau Mantehage, Sulawesi Utara. Jurnal Ilmiah Platax, 1(4): 177186.

Sundaravarman K, Varadharajan D, Babu A, Saravanakumar A,Vijayalakshmi S, Balasubramania T. 2012. A Study of marine benthic fauna with special reference to the environmental parameters, South East Coastal of India. Intl. J. Pharm. Biol. Arch., 3 (5): 11571169.

Susetiono. 2004. Fauna padang lamun tanjung merah selat lembeh. Pusat Penelitian Oseanografi-LIPI. Jakarta.

Trisnawaty F.N., Emiyarti, Afu L.O.A. 2013. Hubungannya Kadar Logam Berat Merkuri (Hg) pada Sedimen dengan Struktur Komunitas Makrozoobenthos di Perairan Sungai TahiIte, Kecamatan Rarowatu, Kabupaten Bombana. Mina Laut Indonesia, 3 (12): 68-80. 